Katedra Ekonomiki Rolnictwa i Międzynarodowych Stosunków Gospodarczych SGGW

\title{
Procesy koncentracji w polskim sektorze bankowym
}

\section{Wstęp}

Koncentracja kapitału jest procesem, który w dużym stopniu dotyczy sektora finansowego. Obserwowany jest we wszystkich krajach posiadających gospodarkę rynkową i dokonuje się przede wszystkim poprzez fuzje i przejęcia. Trend konsolidacyjny sektora bankowego w Europie spowodowany jest deregulacją tego sektora, odchodzeniem od ochrony państwa, liberalizacją europejskiego rynku, wreszcie rosnącą konkurencją na rynkach finansowych na kontynencie i na świecie, zmuszającą banki europejskie do poszukiwania zewnętrznych możliwości wzrostu. Sposobami na szybki rozwój banków i ich ekspansję na nowe rynki oraz budowanie silniejszej pozycji na dotychczasowych rynkach są więc przejmowanie innych banków lub fuzje bankowe ${ }^{1}$. Banki międzynarodowe znalazły w latach 90 . i na początku XXI wieku dobre warunki dla działalności na rynkach Europy Środkowej, w tym również w Polsce. Transformacja systemu polityczno-ekonomicznego, $\mathrm{w}$ tym procesy prywatyzacyjne, doskonalenie podstaw legislacyjnych, liberalizowanie dostępu do rynku, stabilizowanie warunków makroekonomicznych i akcesja do UE stworzyły sprzyjające możliwości dla ekspansji inwestycyjnej zagranicznych banków w polskim sektorze bankowym. Od poczatku lat 90 . napływające do Polski inwestycje zagraniczne są lokowane w sektorze bankowym. Do 1993 r. w działalność finansową zainwestowano $288 \mathrm{mln}$ USD, od tego czasu wartość inwestycji zwiększyła się do 16,2 mld USD w 2003 r. ${ }^{2}$. W sektorze bankowym zaczęły działać korporacje wielonarodowe o zasięgu globalnym. Nastapiły zmiany w strukturze własnościowej banków, pojawiły się nowe formy działalności bankowej i innowacyjne produkty.

\footnotetext{
${ }^{1}$ Fuzje i przejęcia bankowe, Zeszyty BRE Bank - CASE nr 45, Warszawa 1999.

${ }^{2}$ Dane $z$ PAIiIZ.
} 
Celem artykułu było ukazanie przyczyn i form koncentracji sektora bankowego w Polsce, a także wpływu przejmowania polskich banków przez zachodnich inwestorów na nasz sektor finansowy.

\section{Przyczyny i formy koncentracji w sektorze bankowym}

Procesy konsolidacji, zachodzące ostatnio z dużą intensywnością związane sq̨ ściśle z procesem globalizacji. Głównym motywem dokonywania przez banki operacji konsolidacyjnych jest dążenie do osiągnięcia korzyści, jakie daje zwiększenie rozmiarów i zakresu działalności. Lączenie się banków pozwala także na osiagnnięcie takich celów, jak: rozszerzenie asortymentu oferowanych produktów, zmniejszenie kosztów stałych działalności banku, zwiększenie liczby posiadanych placówek, co z kolei prowadzi do zwiększenia liczby klientów i obrotów banku, skoncentrowanie funduszy własnych łączących się jednostek czy poprawienie jakości portfela kredytowego. Dzięki konsolidacji banki mogą wykorzystać renomę jednego z łączących się banków do promowania całej połączonej struktury lub uzyskać możliwość wejścia do grupy większych banków o szerszych możliwościach działania. Bardzo prawdopodobne jest także podniesienie poziomu pracy połączonego banku dzięki temu, że jedna z łączących się jednostek jest bankiem bardziej nowoczesnym i lepiej zorganizowanym, który reorganizuje i doskonali działalność drugiej jednostki.

Główną przyczyną przejęć i fuzji w sektorze bankowym jest obecnie dosyć powszechnie występujący pogląd inwestorów oraz kierownictw, że połączenia są skuteczną drogą prowadząca z reguły do wzrostu wartości połączonej instytucji. Pozytywne nastawienie obu tych grup wobec operacji przejęć lub połączeń jest więc racjonalne. Wspomniane procesy koncentracji popierane są również przez menedżerów. Powodem tego jest fakt, iż obecnie coraz częściej ich wynagrodzenie uzależnione jest od wzrostu wartości zarządzanej przez nich firmy. $Z$ tego powodu często do operacji przejęcia pozytywnie odnosi się również kierownictwo podmiotu przejmowanego, ponieważ znajdywane są rozwiązania pozwalające również tej grupie zapewnić uczestnictwo w korzyściach wynikających ze wzrostu wartości połączonej instytucji ${ }^{3}$.

Przyczyny fuzji i przejęć w Polsce można podzielić na wewnętrzne i zewnętrzne. Do wewnętrznych przyczyn konsolidacji, wynikających z osiagnniętego poziomu rozwoju systemu finansowego, należy zaliczyćt :

\footnotetext{
${ }^{3}$ Fuzje i przejęcia bankowe, Zeszyty BRE Bank - CASE nr 45, Warszawa 1999

${ }^{4} \mathrm{M}$. Pawłowska, Wpływ zmian w strukturze polskiego sektora bankowego na jego efektywność w latach 1997-2002, Bank i Kredyt, listopad-grudzień 2003.
} 
1) ciagle jeszcze niski poziom funduszy własnych banków komercyjnych, który nie wystarcza, by sprostać potrzebom finansowania polskiej gospodarki, jak również konkurencji banków zagranicznych,

2) nadmierną liczbę instytucji bankowych w stosunku do potrzeb rynku,

3) brak „masy krytycznej” właściwej dla sektora, niezbędnej do realizacji korzyści skali.

Czynniki zewnętrzne konsolidacji wynikają z procesów transformacji gospodarczej w Polsce i wzrastającej konkurencji międzynarodowej na rynku krajowym oraz poza granicami kraju.

Operacje konsolidacyjne polegają na łączeniu się kilku samodzielnych dotychczas jednostek w jedną strukturę organizacyjna, w ramach której łączące się jednostki bądź całkowicie tracą swą odrębność i tworzą nowy organizm, bądź też zachowują swą osobowość i pewien zakres samodzielności. W każdym przypadku powstaje struktura większa i silniejsza finansowo, o zwiększonych zasobach kapitałowych, mogąca łatwiej sprostać zaostrzonej konkurencji na rynkach krajowych i międzynarodowych.

Konsolidacja banków może być realizowana w różnych formach. Najbardziej rozpowszechnione $\mathrm{z}$ nich to: fuzje banków, przejęcia oraz tworzenie konglomeratów finansowych i bankowych grup kapitałowych.

Największe znaczenie w procesach koncentracji firm sektora bankowego mają fuzje i przejęcia.

Fuzja polega na łączeniu się niezależnych przedsiębiorstw, które dzielą się swoimi zasobami dla osiągnięcia wspólnych celów. Cechą charakterystyczną fuzji jest dobrowolne działanie partnerów, zwykle podobnych pod względem wielkości. Fuzje mogą przyjmować dwie formy:

- egalitarna czyli konsolidację (ang. consolidation); w tym przypadku dwa lub więcej przedsiębiorstw poczatkowo autonomicznych, w wyniku umowy łączy się ze sobą dla stworzenia nowego przedsiębiorstwa, każde z nich traci dotychczasową odrębność i osobowość prawna, łączone jednostki ulegają likwidacji, wypisowi z rejestru, a zamiast nich powstaje nowa firma i nowy podmiot prawny.

- wchłonięcia, inkorporacji (ang. merger) - jest to połączenie dwóch lub więcej przedsiębiorstw w jedno dla osiągnięcia wspólnych celów, przy czym tylko przedsiębiorstwo-nabywca zachowuje tożsamość (firmę) i podmiotowość (osobowość prawna), a druga firma przestaje istnieć ${ }^{5}$.

${ }^{5}$ Ł. Gębski, Fuzje i wykupy, Gdańska Akademia Bankowa, Gdańsk 1998. 
Przez przejęcie rozumiemy natomiast nabycie takiej liczby akcji jednego przedsiębiorstwa przez drugie, która daje możliwość jego kontrolowania ${ }^{6}$. W wyniku przejęcia wykupione przedsiębiorstwo zostaje $\mathrm{w}$ pewien sposób włączone w strukturę firmy przejmującej. Cechą odróżniającą przejęcia od fuzji jest to, że przejmowane przedsiębiorstwo nie traci podmiotowości prawnej.

W ostatnich latach obserwujemy wyraźną tendencję tworzenia konglomeratów finansowych. Jest to reakcja banków na nasilającą się konkurencję ze strony instytucji parabankowych i zarazem jedna $\mathrm{z}$ form konsolidacji. Konglomeraty finansowe oferują swoim klientom w jednym zespole instytucji pełen komplet usług finansowych: bankowych, maklerskich czy ubezpieczeniowych, co zapobiega odpływowi klientów do innych obszarów rynku finansowego.

Także tworzenie bankowych grup kapitałowych jest jedną z form konsolidacji. Bankową grupę kapitałową tworzy na mocy dobrowolnie zawartej umowy kilka banków, które podejmują stałą współpracę i koordynują swoje działania, tworząc jednocześnie między sobą powiązania kapitałowe. Zgodnie $\mathrm{z}$ umową, jeden $\mathrm{z}$ banków wchodzących $\mathrm{w}$ skład grupy określany jest jako dominujący, obejmuje kluczowe pakiety akcji pozostałych banków, które stają się bankami zależnymi. Banki zależne zachowują samodzielność operacyjną i działają nadal pod dotychczasową firmą z zastrzeżeniem, że należą także do danej grupy. Wszystkie banki należące do grupy zobowiązują się do udzielenia pomocy bankowi, który znajdzie się w tarapatach finansowych. Każdy z banków odpowiada także za zobowiązania pozostałych członków grupy proporcjonalnie do posiadanych akcji. Dzięki temu cały zespół jednostek tworzy połączoną konstrukcję finansową; a o sytuacji finansowej każdej jednostki decydują zasoby kapitałowe całej grupy.

Szczególną odmianą bankowej grupy kapitałowej jest holding, w którym zamiast banku dominującego występuje spółka holdingowa. Spółka holdingowa nie jest bankiem, lecz jedynie posiadaczem kluczowych pakietów akcji jednostek zależnych. Najczęściej banki tworzą holding w celu połączenia wysiłków finansowych wspólników i realizacji przedsięwzięcia przekraczającego możliwości każdego $\mathrm{z}$ nich $\mathrm{z}$ osobna. Holding finansowy jest specyficzną formą holdingu, gdyż w przeciwieństwie do innych holdingów charakteryzuje go jednorodność. Zgodnie bowiem z polskimi uregulowaniami prawnymi, w skład holdingu finansowego moga wchodzić wyłącznie banki lub instytucje finansowe. Związek kapitałowo-organizacyjny przybierający formę holdingu chroni instytucje finansowe, przenosząc indywidualne ryzyko jednostkowe na ryzyko całej grupy, prowadzi także do obniżki kosztów, poprawy jakości, stwarza

\footnotetext{
${ }^{6} \mathrm{P}$. Bożyk (red.), Egzemplifikacja międzynarodowych stosunków gospodarczych, WSHiP, Warszawa 2004.
} 
szansę lepszej obsługi klienta. Jednocześnie niezbędne są specjalistyczna wiedza fachowa oraz kapitał na pokrycie ryzyka związanego $\mathrm{z}$ różnego rodzaju operacjami finansowymi ${ }^{7}$.

\section{Napływ inwestycji zagranicznych do polskiego sektora bankowego}

Ekspansja inwestycji zagranicznych do sektora bankowego była uwarunkowana przepisami prawnymi - polityką licencyjną oraz polityką prywatyzacyjna. Napływ inwestycji zagranicznych do sektora bankowego umożliwiło wprowadzone w 1989 r. prawo bankowe, zgodnie $\mathrm{z}$ nim możliwe było tworzenie podmiotów $z$ kapitałem zagranicznym $w$ sektorze usług bankowych. W celu zachęcenia inwestorów do lokowania kapitału w Polsce stworzono korzystne warunki zakładania banków, m.in.: wakacje podatkowe w ciąu pierwszych 3 lat, swobodę transferu $15 \%$ zysków, wnoszenie i utrzymywanie kapitału w walutach obcych ${ }^{8}$. Pierwszymi bankami zagranicznymi utworzonymi.w Polsce były: Bank Amerykański w Polsce SA, Raiffeisen Centrobank SA, Citibank SA i IBP Bank SA. Liberalna polityka licencyjna NBP wobec inwestorów zagranicznych trwała do 1992 r., w tym czasie wydano w Polsce 9 licencji bankom z udziałem kapitału zagranicznego. Od 1992 r. polityka NBP wobec inwestorów zagranicznych uległa zaostrzeniu. W latach 1993-1994 wydano 2 licencje na utworzenie banków z kapitałem zagranicznym, jednak od 1993 r. corocznie zwiększa się liczba inwestorów zagranicznych w sektorze bankowym. W 1993 r. w tym sektorze działało 87 banków komercyjnych. Banki te w przewadze były własnością polskiego kapitału, w tym 29 było kontrolowanych przez państwo, a 48 przez polski kapitał prywatny. Inwestorzy zagraniczni w 1993 r. kontrolowali 10 banków, a w 1994 r. -11.

W kolejnych latach liczba banków kontrolowanych przez inwestorów zagranicznych zwiększała się. Było to wynikiem zmiany polityki NBP wobec inwestorów zagranicznych, zostali oni włączeni do procesu restrukturyzacji i prywatyzacji. W okresie 1995-1998 inwestorzy zagraniczni utworzyli 10 nowych banków i przejęli kontrolę nad 7 bankami wymagającymi dokapitalizowania ${ }^{9}$.

\footnotetext{
${ }^{7}$ A. Tarasek, Bankowość wobec procesów globalizacji, Uniwersytet Gdański, Gdańsk-Jurata 2003, s. 383-388.

${ }^{8}$ Por. System bankowy w Polsce w latach dziewięćdziesiątych. Raport NBP, Warszawa 2001, s. 56.

${ }^{9} \mathrm{JW} .$, s. 57.
} 
W 1996 r. Polska przystapiła do OECD, a to spowodowało w kolejnych latach zliberalizowanie polityki licencyjnej, czyli zniesienie ograniczeń wobec banków zagranicznych. W 1998 r. inwestorzy zagraniczni kontrolowali 31 banków komercyjnych. Od 1999 r. występuje całkowita swoboda zakładania w Polsce banków zagranicznych. Do 1998 r. przewagę liczebną w sektorze bankowym posiadał polski kapitał, jednak w kolejnych latach zdecydowanie zmniejszał się udział podmiotów krajowych na korzyść inwestorów zagranicznych. W 2003 r. na 60 banków komercyjnych działających w Polsce 47 było kontrolowanych przez inwestorów zagranicznych (tab. 1).

\section{Tabela 1}

Lịczba banków w Polsce w latach 1993 - I kw. 2004 ze względu na strukturę własnościową

\begin{tabular}{|l|c|c|c|c|c|c|c|c|c|c|c|c|}
\hline \multirow{2}{*}{$\begin{array}{l}\text { Wyszczególnie- } \\
\text { nie }\end{array}$} & 1993 & 1994 & 1995 & 1996 & 1997 & 1998 & 1999 & 2000 & 2001 & 2002 & 2003 & $\begin{array}{l}2004 \\
-1 \\
\mathrm{kw}\end{array}$ \\
\cline { 2 - 13 } \\
\hline $\begin{array}{l}\text { Banki komer- } \\
\text { cyjne, w tym } \\
\text { z przewaga: }\end{array}$ & 87 & 82 & 81 & 81 & 83 & 83 & 77 & 74 & 71 & 62 & 60 & 59 \\
\hline $\begin{array}{l}\text { 1) kapitału } \\
\text { państwowego }\end{array}$ & 29 & 29 & 27 & 24 & 15 & 13 & 7 & 7 & 7 & 8 & 7 & 7 \\
\hline $\begin{array}{l}\text { 2) kapitału } \\
\text { prywatnego, } \\
\text { w tym kontrolo- } \\
\text { wane przez: } \\
\text { 2.1) inwestorów } \\
\text { polskich } \\
\text { 2.2) inwestorów } \\
\text { zagranicznych }\end{array}$ & 58 & 53 & 45 & 57 & 68 & 70 & 70 & 67 & 64 & 54 & 53 & 53 \\
\hline $\begin{array}{l}\text { Banki spółdziel- } \\
\text { cze }\end{array}$ & 1653 & 1612 & 1510 & 1394 & 1295 & 1189 & 781 & 680 & 642 & 605 & 600 & 598 \\
\hline $\begin{array}{l}\text { Cały sektor } \\
\text { bankowy }\end{array}$ & 1740 & 1694 & 1591 & 1475 & 1378 & 1272 & 858 & 754 & 713 & 667 & 660 & 657 \\
\hline
\end{tabular}

Źródło: System bankowy w Polsce w latach dziewięćdziesiątych. Raport NBP, Warszawa 2001.

Ze struktury własnościowej banków wynika, że do 1998 r. przewage w sektorze bankowym miał kapitał polski, a po 1998 r. dominował kapitał zagraniczny (rys. 1). Z danych Generalnego Inspektoratu Nadzoru Bankowego wynika, że na koniec 2003 r. wartość inwestycji zagranicznych w polskim sektorze bankowym wynosiła 7316,1 mln zł (była najwyższa w historii sektora bankowego), od 1995 r. wzrosła ponad 12-krotnie. W I kwartale 2004 r. kwota inwestycji zagranicznych uległa zmniejszeniu o 1,5\% do 7203,0 mln zł, co było efektem m.in. likwidacji Bankgesellschaft Berlin. W I kwartale 2004 r. udział 
inwestorów zagranicznych $\mathrm{w}$ kapitale zakładowym sektora wynosił $60,1 \%$, (14,4\% posiadał Skarb Państwa, 9,8\% drobni akcjonariusze, 4,3\% banki spółdzielcze, 2,1\% państwowe osoby prawne i $9,3 \%$ pozostałe podmioty krajowe), a w kapitale banków komercyjnych 63,3\%.

Do banków kontrolowanych przez inwestorów zagranicznych w I kwartale 2004 r. należało 76,3\% funduszy własnych i uzupełniających sektora bankowego, wobec $76,7 \%$ w 2003 r. i 2,2\% w 1993 r. Aktywa tych banków stanowiły $67,4 \%$ (338 415,4 mln zl) wobec $67,8 \%$ na koniec 2003 r. i 2,6\% w 1993 r. Banki kontrolowane przez inwestorów zagranicznych udzieliły prawie $70 \%$ ogółu kredytów netto dla sektora niefinansowego i zgromadziły $62 \%$ ogółu depozytów (rys. 2).

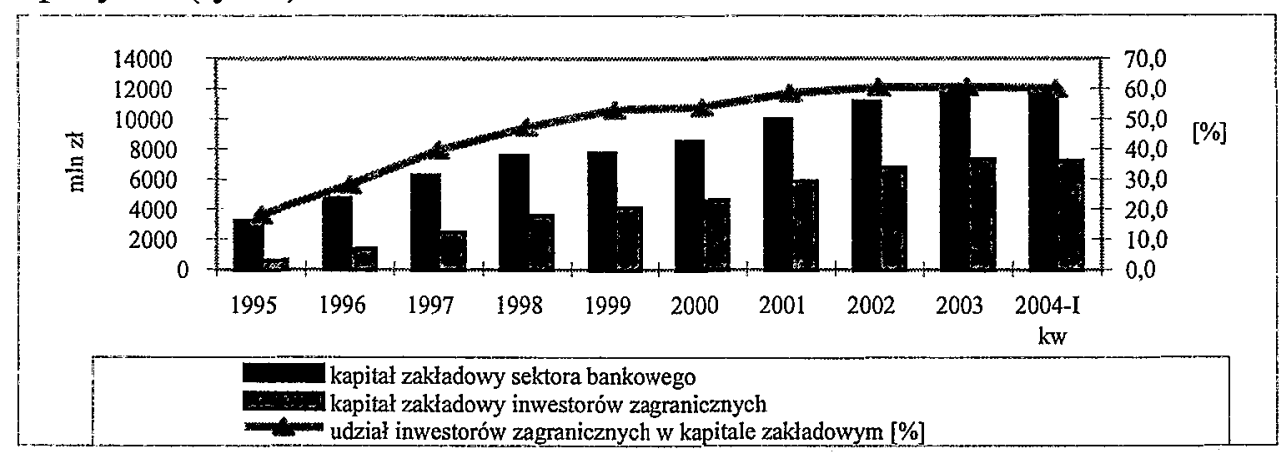

\section{Rysunek 1}

Struktura własnościowa sektora bankowego w latach 1995-2004 (I kwartał) oś lewa odnosi się do wartości inwestycji ogölem i w pośrednictwie finansowym oś prawa odnosi się do udziału inwestycji z sektora finansowego Źródło: Opracowanie wlasne na podstawie danych NBP.

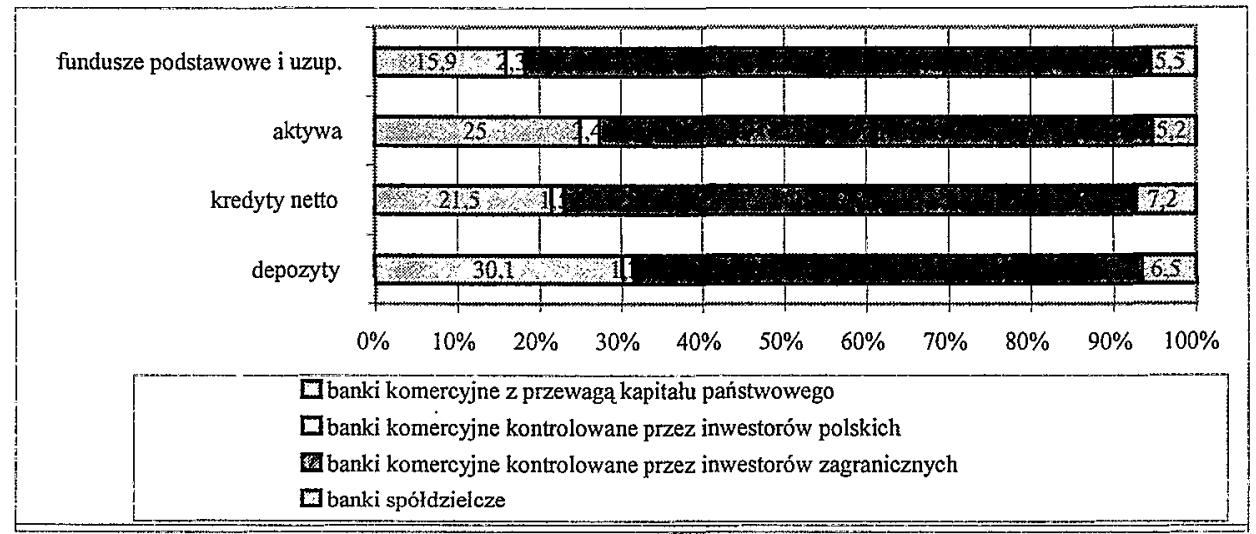

Rysunek 2

Struktura udzialu poszczególnych grup banków w wybranych kategoriach charakteryzujących sektor bankowy w I kwartale $2004 \mathrm{r}$.

Źródło: Opracowanie wlasne na podstawie danych NBP. 
Inwestorzy zagraniczni lokowali kapitał $\mathrm{w}$ bankach giełdowych, a ich udział w kapitale zakładowym wynosił 78,4\%. W 2003 r. kapitał zagraniczny zaangażowany $w$ bankach giełdowych wynosił ponad 3,5 mld zł i stanowił około $48 \%$ kapitału wniesionego przez podmioty zagraniczne do sektora bankowego ${ }^{10}$.

Inwestorzy zagraniczni z sektora bankowego pochodzili z 15 państw, w tym głównie z Unii Europejskiej i USA. W I kwartale 2004 r. największy udział posiadali inwestorzy niemieccy - zainwestowali oni w 13 bankach kwotę 1,6 mld zł. Na drugiej pozycji pod względem wartości zainwestowanego kapitału byli inwestorzy amerykańscy. Podmioty z USA kontrolowały 7 banków, ich udział w kapitale zakładowym banków komercyjnych wynosił ponad $10 \%$, a w aktywach $-8,8 \%$ (tab. 2 i 3 ).

\section{Tabela 2}

Kapitał zagraniczny w sektorze bankowym według krajów pochodzenia (stan na I kwartał 2004 r.)

\begin{tabular}{|l|c|c|c|c|}
\hline Kraj pochodzenia & $\begin{array}{c}\text { Wartość bez- } \\
\text { pośrednich } \\
\text { inwestycji } \\
{[\text { mIn zł] }}\end{array}$ & $\begin{array}{c}\text { Udział w kapi- } \\
\text { tale zakłado- } \\
\text { wym banków } \\
\text { komercyjnych } \\
{[\%]}\end{array}$ & $\begin{array}{c}\text { Udział w akty- } \\
\text { wach banków } \\
\text { komercyjnych } \\
{[\%]}\end{array}$ & Liczba banków \\
\hline Niemcy & 1663,0 & 14,50 & 18,0 & 13 \\
\hline USA & 1155,4 & 10,07 & 8,8 & 7 \\
\hline Belgia & 889,8 & 7,76 & 5,6 & 2 \\
\hline Holandia & 768,5 & 6,70 & 7,4 & 4 \\
\hline Irlandia & 514,1 & 4,48 & 4,9 & 4 \\
\hline Francja & 454,4 & 3,96 & 2,2 & 4 \\
\hline Szwecja & 427,4 & 3,73 & 1,0 & 2 \\
\hline Portugalia & 424,6 & 3,70 & 3,9 & 1 \\
\hline Austria & 407,0 & 3,55 & 1,7 & 1 \\
\hline Wielka Brytania & 165,5 & 1,44 & 0,0 & 1 \\
\hline Pozostałe kraje & 333,3 & 2,91 & 13,8 & 6 \\
\hline Razem inwesto- & 7203,0 & 62,8 & 67,3 & 45 \\
\hline rzy zagraniczni & 720 & & \\
\hline
\end{tabular}

Źródło: Opracowanie własne na podstawie danych NBP.

W ostatnich latach w sektorze bankowym wzrosło zaangażowanie kapitału brytyjskiego, francuskiego, belgijskiego i szwedzkiego, a zmniejszało się kapitału amerykańskiego, włoskiego i niemieckiego. Od $2000 \mathrm{r}$. w polskim sektorze bankowym inwestują podmioty ze Szwecji i Danii, od 2002 r. z Cypru, a od 2003 r. z Hiszpanii.

${ }^{10}$ Durka B., Chojna J. (red.): Inwestycje zagraniczne w Polsce. IKiCHZ, Warszwa 2004, s. 109. 
Tabela 3

Kapital zagraniczny w polskim sektorze bankowym w 2004 r.

\begin{tabular}{|c|c|c|c|c|}
\hline Lista banków & $\begin{array}{c}\text { Inwestor zagra- } \\
\text { niczny }\end{array}$ & $\begin{array}{c}\text { Zainwesto- } \\
\text { wany kapitał }^{1} \\
\text { [mln USD] }\end{array}$ & $\begin{array}{l}\text { Pocho- } \\
\text { dzenie } \\
\text { inwestora }\end{array}$ & $\begin{array}{l}\text { Udział } \\
\text { inwestora } \\
\text { w kapitale } \\
\text { zakłado- } \\
\text { wym [\%] }\end{array}$ \\
\hline 1 & 2 & 3 & 4 & 5 \\
\hline \multicolumn{5}{|c|}{ Spólki akcyjne ze 100-procentowym udziałem kapitału zagranicznego } \\
\hline $\begin{array}{l}\text { HSBC Bank Polska SA } \\
\text { (do } 12.01 .04 \text { Polski } \\
\text { Kredyt Bank SA) } \\
\end{array}$ & HSBC & bd & $\begin{array}{l}\text { Wielka } \\
\text { Brytania }\end{array}$ & 100 \\
\hline $\begin{array}{l}\text { Dresdner Bank Polska } \\
\text { SA }\end{array}$ & Dresdner Bank & bd & Niemcy & 100 \\
\hline $\begin{array}{l}\text { DaimlerChrysler Serv- } \\
\text { ices Bank Polska SA }\end{array}$ & $\begin{array}{c}\text { DaimlerChrysler } \\
\text { AG }\end{array}$ & $42,7 \mathrm{mln} z \nmid$ & Niemcy & 100 \\
\hline ABN AMRO BANK SA & $\begin{array}{c}\text { ABN AMRO BANK } \\
\text { NV }\end{array}$ & 96,7 & Holandia & 100 \\
\hline $\begin{array}{l}\text { GE Capital Bank SA } \\
\text { GE Bank Mieszkaniowy } \\
\text { SA }\end{array}$ & $\begin{array}{l}\text { GE Capital Interna- } \\
\text { tional Finacing }\end{array}$ & bd & USA & 93,68 \\
\hline $\begin{array}{l}\text { Raiffeinsen Bank Pol- } \\
\text { ska SA }\end{array}$ & $\begin{array}{c}\text { Raiffeinsen Zen- } \\
\text { tralbank Osterreich } \\
\text { AG } \\
\text { Centro Internation- } \\
\text { ale Handelsbank }\end{array}$ & $\begin{array}{l}108,8 \\
20,6\end{array}$ & $\begin{array}{l}\text { Austria } \\
\text { Austria }\end{array}$ & $\begin{array}{l}75 \\
25\end{array}$ \\
\hline $\begin{array}{l}\text { Credit Lyonnais Bank } \\
\text { Poiska SA }\end{array}$ & $\begin{array}{l}\text { Credit Lyonnais } \\
\text { Global Banking }\end{array}$ & 48 & Francja & bd \\
\hline $\begin{array}{l}\text { Danske Bank Polska } \\
\text { SA }\end{array}$ & Danske Bank SA & 121,8 & Dania & 98,33 \\
\hline $\begin{array}{l}\text { BNP Paribas Bank } \\
\text { Polska SA }\end{array}$ & BNP Paribas & 61,2 & Francja & 100 \\
\hline $\begin{array}{l}\text { WestLB Bank Polska } \\
\text { SA }\end{array}$ & WestLB AG & $183,6 \mathrm{mln} z \nmid$ & Niemcy & 100 \\
\hline $\begin{array}{l}\text { Deutsche Bank Polska } \\
\text { SA }\end{array}$ & Deutsche Bank AG & 319,9 & Niemcy & 95,02 \\
\hline GMAC Bank Polska SA & $\begin{array}{c}\text { General Motors } \\
\text { Acceptance Corpo- } \\
\text { ration } \\
\end{array}$ & $b d$ & USA & 100 \\
\hline Rabobank Polska SA & $\begin{array}{l}\text { Rabobank Interna- } \\
\text { tional Holding BV }\end{array}$ & 21,4 & Holandia & 100 \\
\hline FCE Bank Polska SA & $\begin{array}{c}\text { Ford Credit Bank } \\
\text { Plc }\end{array}$ & 9,6 & $\begin{array}{l}\text { Wielka- } \\
\text { Brytania }\end{array}$ & 100 \\
\hline CC - BANK SA & $\begin{array}{c}\text { Santander Central } \\
\text { Hispano }\end{array}$ & 50 & Hiszpania & 100 \\
\hline
\end{tabular}


cd. tabeli 3

\begin{tabular}{|c|c|c|c|c|}
\hline 1 & 2 & 3 & 4 & 5 \\
\hline $\begin{array}{l}\text { VOLKSWAGEN BANK } \\
\text { POLSKA SA }\end{array}$ & $\begin{array}{c}\text { VOLKSWAGEN } \\
A G\end{array}$ & bd & Niemcy & 100 \\
\hline Fiat Bank Polska SA & Fiat & bd & Whochy & 100 \\
\hline Toyota Bank Polska SA & Toyota & bd & Japonia & 100 \\
\hline $\begin{array}{l}\text { NORD/LB Bank Polska } \\
\text { Norddeutsche } \\
\text { Landesbank SA }\end{array}$ & $\begin{array}{c}\text { NORD/LB } \\
\text { Norddeutsche Giro } \\
\text { Zantrala }\end{array}$ & $200 \mathrm{mln} z$ & Niemcy & 100 \\
\hline $\begin{array}{l}\text { Bank Svenska } \\
\text { Handelsbanken SA }\end{array}$ & $\begin{array}{c}\text { Svenska } \\
\text { Handelsbanken }\end{array}$ & 81 & Szwecja & 100 \\
\hline $\begin{array}{l}\text { Bank of Tokyo - Mitsu- } \\
\text { bishi SA }\end{array}$ & $\begin{array}{c}\text { Bank of Tokyo - } \\
\text { Mitsubishi }\end{array}$ & 30,3 & Japonia & 100 \\
\hline $\begin{array}{l}\text { Nykredit Bank Hopo- } \\
\text { teczny }\end{array}$ & $\begin{array}{c}\text { Nykredit Realkredis } \\
\text { AVS } \\
\end{array}$ & $75 \mathrm{~min} z \nmid$ & Dania & 100 \\
\hline \multicolumn{5}{|c|}{ Spółki akcyjne $z$ większościowym udziałem kapitału zagranicznego } \\
\hline $\begin{array}{l}\text { Bank Handlowy } \\
\text { w Warszawie }\end{array}$ & $\begin{array}{l}\text { Citigroup Citibank } \\
\text { Overseas Invest- } \\
\text { ment Corporation }\end{array}$ & 1300 & USA & 89,33 \\
\hline ING Bank Śląski SA & ING Group NV & 990 & Holandia & 87,77 \\
\hline $\begin{array}{l}\text { Bank Przemysłowo- } \\
\text { Handlowy SA (Bank } \\
\text { BPH SA) }\end{array}$ & HVB Group & $\cdot 1336$ & Niemcy & 71,24 \\
\hline $\begin{array}{l}\text { Bank Zachodni WBK } \\
\text { SA }\end{array}$ & $\begin{array}{l}\text { Allied Irish Banks } \\
\text { European Invest- } \\
\text { ments Limitem }\end{array}$ & 746,7 & Irlandia & 70,5 \\
\hline BRE Bank SA & Commerzbank AG & 300,1 & Niemcy & 72,16 \\
\hline $\begin{array}{l}\text { Deutsche Bank PBC } \\
\text { SA }\end{array}$ & Deutsche Bank & jw. & jw. & jw. \\
\hline Bank Millennium SA & $\begin{array}{c}\text { Banco Commercial } \\
\text { Portugues SA }\end{array}$ & 28 & Portugalia & 50,0 \\
\hline $\begin{array}{l}\text { Bank Polska Kasa } \\
\text { Opieki SA (Pekao) } \\
\end{array}$ & $\begin{array}{c}\text { UniCredito Italiano } \\
\text { SpA }\end{array}$ & 1200,0 & Wlochy & 53,05 \\
\hline $\begin{array}{l}\text { Nordea Bank Polska } \\
\text { SA }\end{array}$ & $\begin{array}{c}\text { Nordea Bank } \\
\text { Sweden }\end{array}$ & $\begin{array}{l}279,0 \\
24,4 \\
\end{array}$ & $\begin{array}{c}\text { Szwecja } \\
\text { Dania }\end{array}$ & 98,35 \\
\hline Kredyt Bank SA & KBC Bank N.V. & 1290 & Belgia & 81,4 \\
\hline Bank Przemysłowy SA & Union Group SA & 17,8 & Czechy & 84,3 \\
\hline $\begin{array}{l}\text { FORTIS BANK POL- } \\
\text { SKA SA }\end{array}$ & $\begin{array}{c}\text { FORTIS BANK } \\
\text { NV/S.A. }\end{array}$ & 178,5 & Belgia & 99,1 \\
\hline $\begin{array}{l}\text { DZ. BANK Polska SA } \\
\text { (AmerBank) }\end{array}$ & $\begin{array}{c}\text { Deutsche Zantral } \\
\text { Bank AG } \\
\end{array}$ & 28,6 & Niemcy & 99,99 \\
\hline AIG Bank Polska SA & AIG & 10 & USA & 99,92 \\
\hline $\begin{array}{l}\text { RHEINHYP-BRE Bank } \\
\text { Hipoteczny SA }\end{array}$ & Eurohypo AG & 675 tys. akcji & Niemcy & bd \\
\hline
\end{tabular}


cd. tabeli 3

\begin{tabular}{|l|c|c|c|c|}
\hline 1 & 2 & 3 & 4 & 5 \\
\hline \multicolumn{1}{|c|}{ Spókki akcyjne pośrednio kontrolowane przez inwestorów zagranicznych } \\
\hline $\begin{array}{l}\text { Wschodni Bank } \\
\text { Cukrownictwa SA }\end{array}$ & grupy bankowe & bd & mieszany & bd \\
\hline $\begin{array}{l}\text { Górnośląski Bank } \\
\text { Gospodarczy SA }\end{array}$ & $\begin{array}{c}\text { HVB BPH PBK SA } \\
\text { w maju O4 sprze- } \\
\text { dane Genin Serni- } \\
\text { ce Provider SA }\end{array}$ & bd & mieszany & 71,2 \\
\hline $\begin{array}{c}\text { Merrill Lynch } \\
\text { Global Emerging } \\
\text { Markets Partners } \\
\text { LP }\end{array}$ & bd & mieszany & 100 \\
\hline $\begin{array}{l}\text { HypoVereinsbank Bank } \\
\text { Hipoteczny SA }\end{array}$ & HVB BPH PBK SA & bd & $\begin{array}{c}\text { Niemcy } \\
\text { Austria }\end{array}$ & 100 \\
\hline LUKAS Bank SA & $\begin{array}{c}\text { Caisse Nationale } \\
\text { de Credit Agricole }\end{array}$ & 740 & Francja & bd \\
\hline Sląski Bank Hipoteczny & ING Bank NV & jw. & Holandia & jw. \\
\hline \multicolumn{1}{|c|}{ Banki z mniejszościowym udziałem kapitału zagranicznego } \\
\hline $\begin{array}{l}\text { Bank Ochrony Środo- } \\
\text { wiska SA }\end{array}$ & $\begin{array}{c}\text { Skandinanska } \\
\text { Enskilda Banken }\end{array}$ & 44,6 & Szwecja & 47,04 \\
\hline $\begin{array}{l}\text { Bank Inicjatyw Spo- } \\
\text { leczno-Ekonomicznych } \\
\text { SA }\end{array}$ & Credit Cooperatif & 26,7 mln zł & Francja & 37,91 \\
\hline INVEST-BANK SA & grupy bankowe & bd & mieszany & bd \\
\hline
\end{tabular}

${ }^{1}$ Dane podane $w$ mln zł pochodzą $z$ poszczególnych banków, pozostałe dane pochodzą $z$ listy inwestorów zagranicznych publikowanej przez PAliz, są podane w mln USD. ${ }^{2}$ Stan na 31.12.2003. ${ }^{3}$ od 21.05.04 Calyon Bank Polska.

Źródło: Opracowanie własne na podstawie danych PAlilZ, NBP i informatorów bankowych.

Wśród 45 banków kontrolowanych przez inwestorów zagranicznych 22 banki były ze 100-procentowym udziałem kapitału zagranicznego, 15 banków $\mathrm{z}$ większościowym kapitałem zagranicznym, 6 banków kontrolowanych przez inwestorów zagranicznych i 2 z mniejszościowym udziałem kapitału zagranicznego (tab. 3).

Z danych PAIilZ wynika, że największą wartość inwestycji w sektor bankowy wnieśli ${ }^{11}$ :

- włoski inwestor UniCredito Italiano do PEKAO SA Bank ten jest na drugiej pozycji pod względem wielkości w Polsce, posiada on 798 placówek

\footnotetext{
${ }^{11}$ The list of major foreign investors in Poland 2003 (PAIiIZ, Warszawa) i 50 największych banków w Polsce (Miesięcznik Bank, edycja IX, marzec 2004).
} 
i zatrudnia ponad 16,9 tys. osób. W 2003 r. fundusze własne banku wynosiły $7155 \mathrm{mln} \mathrm{zt}$;

- amerykański inwestor Citigroup - 1300 mln USD do Banku Handlowego w Warszawie. Bank ten posiada 160 placówek, zatrudnia 5 tys. osób, jego fundusze własne na koniec 2003 r. wynosity $5939 \mathrm{mln}$ zł;

- belgijski inwestor KBC Bank N.V. - 1290 mln USD do Kredyt Bank SA Bank ten posiada 359 placówek i zatrudnia prawie 6,9 tys. osób, fundusze własne banku wynoszą $1455 \mathrm{mln} \mathrm{z}$;

- niemiecki inwestor HVB Group - 1336 mln USD do Banku PrzemysłowoHandlowego SA Bank ten posiada 471 placówek i zatrudnia ponad 10 tys. osób, jego fundusze własne w $2003 \mathrm{r}$. wynosiły $5369 \mathrm{mln} \mathrm{zł}$;

- holenderski ING Group - 990 mln USD w Bank Śląski. Bank ten posiada 331 placówek i zatrudnia 6,8 tys. osób, a jego fundusze własne wynoszą 2719 mln zl.

Szczegółowe informacje dotyczące pozostałych inwestorów zagranicznych w sektorze bankowym przedstawia tabela 3 .

\section{Fuzje i przejęcia w sektorze bankowym w Polsce}

Zgodnie $\mathrm{z}$ tendencjami na światowych rynkach, w Polsce w ostatnich latach obserwowane jest nasilenie procesów konsolidacyjnych. Biorąc pod uwage pierwszą połowę lat dziewięćdziesiątych, można powiedzieć, że do przejęć i fuzji banków w Polsce dochodziło dzięki możliwości łatwego wykupu słabych ekonomicznie podmiotów. Tworzone na początku lat dziewięćdziesiątych banki były niedokapitalizowane, zacofane informatycznie i usługowo oraz nieefektywnie zarządzane, co prowadziło do ich upadków lub łatwego przejęcia. Transakcje przejęcia stanowiły przy tym podstawową metodę konsolidacji sektora i umożliwiały stosunkowo łatwe wejście na polski rynek nowym podmiotom $\mathrm{z}$ zagranicy. Fuzje, szczególnie w samym procesie prywatyzacji, odgrywały marginalną rolę. W drugiej połowie lat dziewięćdziesiątych konsolidacja wiązała się już z poprawą konkurencyjności banków, zwiększeniem ich innowacyjności oraz dywersyfikacją źródeł zysku ${ }^{12}$.

W efekcie zmian w systemie bankowym (połączeń, przejęć i likwidacji banków) liczba banków komercyjnych prowadzących działalność operacyjną zmniejszyła się z 85 (na koniec 1997 r.) do 59 (w I kwartale 2004 r.).

\footnotetext{
${ }^{12}$ M. Buszko, Konsolidacja sektorów bankowych w krajach rozwijających się - współczesne tendencje w zakresie fuzji i przejęć, Bank i Kredyt, marzec 2003.
} 
Połączenia przeprowadzone $w$ latach 1997-2004 były naturalną konsekwencją wcześniejszej .prywatyzacji banków krajowych, pozyskania dla nich inwestorów strategicznych oraz nasilających się fuzji w skali globalnej, których przyczyną była walka o udział w rynku. W okresie tym dokonano dwudziestu siedmiu fuzji i przejęć ( tab. 4 i 5).

\section{Tabela 4}

Liczba fuzji i przejęć bankowych w Polsce w latach 1997-2002

\begin{tabular}{|l|c|c|c|c|c|c|c|c|}
\hline \multirow{2}{*}{$\begin{array}{l}\text { Wyszczególnie- } \\
\text { nie }\end{array}$} & \multicolumn{9}{|c|}{ Lata } \\
\cline { 2 - 9 } & 1997 & 1998 & 1999 & 2000 & 2001 & 2002 & 2003 & $2004^{*}$ \\
\hline $\begin{array}{l}\text { Liczba fuzji } \\
\text { I przejęć }\end{array}$ & 3 & 2 & 5 & 3 & 6 & 5 & 2 & 1 \\
\hline $\begin{array}{l}\text { Liczba zaanga- } \\
\text { zowanych ban- } \\
\text { ków }\end{array}$ & 9 & 4 & 13 & 6 & 13 & 14 & 4 & 2 \\
\hline
\end{tabular}

*I kwartał.

Źódło: M. Pawłowska, Wpływ zmian w strukturze polskiego sektora bankowego na jego efektywność w latach 1997-2002, Bank i Kredyt, listopad-grudzień 2003.

\section{Tabela 5}

Połączenia banków w latach 1997-2004

\begin{tabular}{|c|c|}
\hline Bank po fuzji lub przejęciu & Banki uczestniczące w procesie fuzji lub przejęcia \\
\hline 1 & 2 \\
\hline \multicolumn{2}{|r|}{1997} \\
\hline $\begin{array}{l}\text { Powszechny Bank Kredytowy } \\
\text { SA }\end{array}$ & $\begin{array}{l}\text { Powszechny Bank Kredytowy SA przejal przedsiębior- } \\
\text { stwo bankowe Bank Morski SA }\end{array}$ \\
\hline BIG Bank Gdański SA & $\begin{array}{l}\text { Bank Gdański SA połączył się z Bankiem Inicjatyw } \\
\text { Gospodarczych SA }\end{array}$ \\
\hline Kredyt Bank PBI SA & $\begin{array}{l}\text { Kredyt Bank SA połączył się z Polskim Bankiem } \\
\text { z Inwestycyjnym SA i przejął kontrolę nad Prosper } \\
\text { Bank SA }\end{array}$ \\
\hline \multicolumn{2}{|r|}{1998} \\
\hline $\begin{array}{l}\text { Bank Handlowy w Warszawie } \\
\text { SA }\end{array}$ & $\begin{array}{l}\text { Bank Handlowy w Warszawie SA przeją kontrolę } \\
\text { kapitałowa nad Bankiem Rozwoju Cukrownictwa SA } \\
\text { w Poznaniu }\end{array}$ \\
\hline BRE Bank SA & $\begin{array}{l}\text { BRE Bank SA połączył się z Polskim Bankiem Roz- } \\
\text { woju SA }\end{array}$ \\
\hline \multicolumn{2}{|r|}{1999} \\
\hline Bank Polska Kasa Opieki SA & $\begin{array}{l}\text { Połączenie grupy kapitałowej zawierającej cztery ban- } \\
\text { ki: Bank Polska Kasa Opieki SA, } \\
\text { Powszechny Bank Gospodarczy SA, Pomorski Bank } \\
\text { Kredytowy SA, Bank Depozytowo-Kredytowy SA } \\
\end{array}$ \\
\hline $\begin{array}{l}\text { Powszechny Bank Kredytowy } \\
\text { SA }\end{array}$ & $\begin{array}{l}\text { Powszechny Bank Kredytowy SA przejąl przedsiębior- } \\
\text { stwo bankowe Pierwszy Komercyjny Bank SA }\end{array}$ \\
\hline
\end{tabular}


cd. tabeli 5

\begin{tabular}{|c|c|}
\hline 1 & 2 \\
\hline $\begin{array}{l}\text { Bank Inicjatyw Społeczno- } \\
\text {-Ekonomicznych SA }\end{array}$ & $\begin{array}{l}\text { Bank Inicjatyw Społeczno-Ekonomicznych SA połączył } \\
\text { się z Bankiem Energetyki SA }\end{array}$ \\
\hline $\begin{array}{l}\text { Bank Przemysłowo- } \\
\text {-Handlowy SA }\end{array}$ & $\begin{array}{l}\text { Bank Przemysłowo-Handlowy SA połączył się z Hypo } \\
\text { Vereisbank Polska SA }\end{array}$ \\
\hline $\begin{array}{l}\text { Bank Wspólpracy Regional- } \\
\text { nej SA }\end{array}$ & $\begin{array}{l}\text { BWR SA przejął część przedsiębiorstwa bankowego } \\
\text { BWR Bank Secesyjny SA }\end{array}$ \\
\hline \multicolumn{2}{|r|}{2000} \\
\hline $\begin{array}{l}\text { Powszechny Bank Kredytowy } \\
\text { SA }\end{array}$ & $\begin{array}{l}\text { Powszechny Bank Kredytowy SA połączył się z Bank } \\
\text { Austria Creditanstalt Poland SA }\end{array}$ \\
\hline $\begin{array}{l}\text { Wielkopolski Bank Kredytowy } \\
\text { SA }\end{array}$ & $\begin{array}{l}\text { Wielkopolski Bank Kredytowy SA przejal przedsiębior- } \\
\text { stwo bankowe Gliwicki Bank Handlowy SA }\end{array}$ \\
\hline $\begin{array}{l}\text { Bank Współpracy Regional- } \\
\text { nej SA }\end{array}$ & $\begin{array}{l}\text { BWR SA przejał przedsiębiorstwo bankowe BWR } \\
\text { REAL BANK SA (na podstawie uchwaly KNB); na- } \\
\text { stępnie doszło do połączenia obu banków }\end{array}$ \\
\hline \multicolumn{2}{|r|}{2001} \\
\hline BIG Bank Gdański SA & BIG Bank Gdański SA połączył się z BIG BANK SA \\
\hline $\begin{array}{l}\text { Bank Handlowy w Warszawie } \\
\text { SA }\end{array}$ & $\begin{array}{l}\text { CITIBANK (Poland) SA połączył się z Bankiem Han- } \\
\text { dlowym w Warszawie SA }\end{array}$ \\
\hline Bank Zachodni - WBK SA & $\begin{array}{l}\text { Wielkopolski Bank Kredytowy SA połączył się z Ban- } \\
\text { kiem Zachodnim SA }\end{array}$ \\
\hline ING Bank Śląski SA & $\begin{array}{l}\text { ING Bank Śląski SA połączył się z Oddziałem ING } \\
\text { Bank N.V. w Warszawie oraz przejał Wielkopolski } \\
\text { Bank Rolniczy SA. }\end{array}$ \\
\hline $\begin{array}{l}\text { Gospodarczy Bank Wielko- } \\
\text { polski SA }\end{array}$ & $\begin{array}{l}\text { Gospodarczy Bank Wielkopolski SA połączył się } \\
\text { z Bałtyckim Bankiem Regionalnym SA }\end{array}$ \\
\hline NORDEA Bank SA & $\begin{array}{l}\text { NORDEA Bank Polska SA połączył się z Bankiem } \\
\text { Własności Pracowniczej - Unibank SA }\end{array}$ \\
\hline \multicolumn{2}{|r|}{2002} \\
\hline $\begin{array}{l}\text { Bank Przemysłowo- } \\
\text {-Handlowy - PBK SA }\end{array}$ & $\begin{array}{l}\text { Powszechny Bank Kredytowy SA połączył się z Ban- } \\
\text { kiem Przemysłowo-Handlowym SA }\end{array}$ \\
\hline Kredyt Bank SA & $\begin{array}{l}\text { Kredyt Bank SA przejał przedsiębiorstwo bankowe } \\
\text { Polski Kredyt Bank SA }\end{array}$ \\
\hline $\begin{array}{l}\text { Bank Polskiej Spółdzielczości } \\
\text { SA }\end{array}$ & $\begin{array}{l}\text { Gospodarczy Bank Poludniowo-Zachodni SA przejął } \\
\text { Małopolski Bank Regionalny SA, } \\
\text { Warmińsko-Mazurski Bank Regionalny SA, Bank Unii } \\
\text { Gospodarczej, Lubelski Bank } \\
\text { Regionalny SA, Rzeszowski Bank Regionalny SA, } \\
\text { Dolnośląski Bank Regionalny }\end{array}$ \\
\hline $\begin{array}{l}\text { Gospodarczy Bank } \\
\text { Wielkopolski SA }\end{array}$ & $\begin{array}{l}\text { Gospodarczy Bank. Wielkopolski SA polączył się } \\
\text { z Pomorsko-Kujawskim Bankiem Regionalnym SA }\end{array}$ \\
\hline
\end{tabular}


cd. tabeli 5

\begin{tabular}{|l|l|}
\hline 1 & \multicolumn{1}{|c|}{2} \\
\hline $\begin{array}{l}\text { Bank Inicjatyw Spoleczno- } \\
\text { Ekonomicznych SA }\end{array}$ & $\begin{array}{l}\text { Bank Jnicjatyw Spoleczno-Ekonomicznych SA przyła- } \\
\text { czył Cukrobank SA. }\end{array}$ \\
\hline & \multicolumn{1}{|c|}{2003} \\
\hline BRE Bank SA & $\begin{array}{l}\text { BRE Bank SA połączył się z Bankiem Częstochowa } \\
\text { SA }\end{array}$ \\
\hline NORDEA Bank Polska SA & $\begin{array}{l}\text { NORDEA Bank Polska SA połączył się z LG Petro } \\
\text { Bankiem SA }\end{array}$ \\
\hline \multicolumn{2}{|c|}{2004} \\
\hline $\begin{array}{l}\text { Bank Przemysłowo-Handlo- } \\
\text { wy PBK SA }\end{array}$ & $\begin{array}{l}\text { Spółdzielczy Bank Rozwoju „SAMOPOMOC CHŁOP- } \\
\text { SKA” polączył się z Bankiem Przemysłowo-Handlo- } \\
\text { wym PBK SA }\end{array}$ \\
\hline
\end{tabular}

Źródło: M. Pawłowska, Wpływ zmian w strukturze polskiego sektora bankowego na jego efektywność w latach 1997-2002, Bank i Kredyt, listopad-grudzień 2003.

Analizując proces fuzji i przejęć zachodzących w ostatnim czasie w polskim systemie bankowym, można wyróżnić następujące typy połączeń:

- połączenie między bankiem krajowym a spółką banku zagranicznego działająca w Polsce (m.in. połączenie Citibanku (Poland) SA z Bankiem Handlowym w Warszawie SA, jako podmiotów bezpośrednio kontrolowanych przez Citibank Overseas Investment Corp., oraz przejęcie ING Bank N.V. oddziału w Warszawie przez ING Bank Śląski SA, którego właścicielem jest ING Bank NV);

- połączenie między dwoma bankami krajowymi mającymi tego samego inwestora zagranicznego (m.in. połączenie Banku Zachodniego SA i Wielkopolskiego Banku Kredytowego SA, które były zależne od Allied Irish Bank European Investments Ltd.);

- połączenie banków działających przedtem w jednej grupie kapitałowej (m.in. przejęcie BIG BANKU SA przez BIG Bank Gdański SA, połączenie Grupy Pekao SA, tj. przyłączenie do Banku Polska Kasa Opieki SA: Powszechnego Banku Gospodarczego SA, Pomorskiego Banku Kredytowego SA i Banku Depozytowo-Kredytowego SA);

- połączenie banków w Polsce będące wynikiem połączenia ich właścicieli poza granicami kraju (m.in. połączenie Banku Własności Pracowniczej z NORDEA Bank Polska, które było rezultatem fuzji duńskiego Uni L ze szwedzko-fińsko-norweską grupa Merita Nordbank, oraz połączenie PBK SA z BPH SA będące efektem fuzji ich właścicieli, tj. Banku Austria Creditanstalt i HypoVereinsbanku). 


\section{Wpływ koncentracji kapitału zagranicznego na rozwój sektora bankowego w Polsce}

Procesy konsolidacyjne sektora bankowego w Polsce, między innymi dzięki wchodzeniu na nasz rynek inwestorów zagranicznych i przejmowaniu banków, spowodowały powstanie specyficznej struktury własnościowej tego sektora, ze znacznym udziałem kapitału obcego. Wysoki udział banków zagranicznych w Polsce wiąże się $\mathrm{z}$ określonymi implikacjami dla finansowania gospodarki. Obecnie widać efekty programów restrukturyzacyjnych wdrażanych w sektorze bankowym. Dzięki wsparciu kapitałowemu i technologicznemu zachodnich partnerów nastapiła istotna poprawa jakości świadczonych usług. W rezultacie działające na polskim rynku instytucje finansowe zdecydowanie powiększyły sieć działających dotychczas placówek, bankomatów, wprowadzając również nowe kanały dystrybucji, a także w wielu przypadkach zdecydowały się na prowadzeniu działalności na odległość, np. przez Internet czy telefon (bankowość mobilna). Dzięki licznym powiązaniom międzynarodowym i wieloletnim doświadczeniom mogły zaoferować o wiele wyższy standard zawierania i realizacji transakcji. Banki krajowe, naśladując działalność banków zagranicznych, mogły wprowadzić sprawdzone i powszechnie znane standardy usług, nie ponosząc większych kosztów. Tworzenie ich od podstaw byłoby bardzo czasochłonne i kosztowne. Banki zagraniczne wchodząc na dany rynek niosą ze sobą wypracowane od dawna metody działania, będące standardowymi usługami na poziomie światowym. Jest to o tyle istotne w krajach rozwijających się, takich jak Polska, gdzie taka nowoczesna praktyka bankowa nie była do tej pory znana. Banki zagraniczne wchodząc na polski rynek bankowy spowodowały zwiększenie się konkurencji na tym rynku, co pociągnęło za sobą nie tylko rozszerzenie oferty ushug, ale także spadek marż, czyli cen usług bankowych. Było to korzystne dla oszczędzających i kredytobiorców zarówno osób prywatnych, jak i przedsiębiorstw.

Warto jednak zwrócić uwage, że banki funkcjonujące w ramach zachodnich grup kapitałowych kładą zdecydowany nacisk na określone segmenty działalności, rezygnując $\mathrm{z}$ finansowania mniej dochodowych sektorów gospodarki. W obecnych realiach widać np. tendencję do zwiększonego zainteresowania udzielaniem kredytów hipotecznych. Zdecydowanie mniejszym zainteresowaniem cieszy się natomiast współpraca $\mathrm{w}$ ramach finansowania przedsiębiorstw.

Silna pozycja zagranicznych instytucji w polskim sektorze bankowym powoduje uzależnienie znaczącej grupy rodzimych podmiotów od trendów na rynku globalnym. W konsekwencji krajowe spółki nie mają możliwości decy- 
dowania, np. o przyszłych aliansach czy też fuzjach na rynku, są bowiem zmuszone do przyjęcia reguł narzuconych już wcześniej przez strategicznych partnerów. Zjawisko to jest szczególnie widoczne w przypadku międzynarodowej współpracy największych potentatów, co później bezpośrednio przekłada się na zależności kapitałowe w naszym kraju ${ }^{13}$.

Kapitał zagraniczny jest zainteresowany rynkami, które są najbezpieczniejsze pod względem ryzyka kredytowego $i$ względnie dochodowe. Prawie wszystkie banki z udziałem kapitału zagranicznego koncentrują się przede wszystkim na obsłudze dużych przedsiębiorstw. Nie oznacza to jednak, że zostaną zaspokojone potrzeby na środki finansowe ze strony tych przedsiębiorstw. Podstawowe założenia strategii danego banku formułowane są na ogół przez centralę; finansowanie niektórych kredytobiorców może nie mieścić się w globalnej strategii lub pozostawać w sprzeczności z interesami dotychczasowych dużych klientów lub akcjonariuszy. Finansowanie małych i średnich przedsiębiorstw, mających istotne znaczenie $\mathrm{z}$ punktu widzenia rozwoju gospodarczego, nie jest na ogół obszarem działania banków o przewadze kapitału zagranicznego. Kredytowanie tej grupy przedsiębiorstw wiąże się $\mathrm{z}$ większą pracochłonnością i ryzykiem, a więc wymaga najczęściej dodatkowych instrumentów wspierania przez państwo ${ }^{14}$.

Zagraniczne banki i inne instytucje finansowe, przejmując stopniowo polskie spółki, wprowadziły zupełnie nowe zasady zarządzania podmiotami. W konsekwencji wdrożenie nowoczesnych systemów informatycznych doprowadziło do znaczącego ograniczenia liczby zatrudnionych w sektorze, a w konsekwencji i do spadku kosztów działalności. Począwszy od 1999 r. zatrudnienie w największych rodzimych instytucjach finansowych systematycznie maleje. O ile w końcu lat dziewięćdziesiątych liczba zatrudnionych dochodziła do 117 tys., to w 2002 r. spadła do prawie 105 tys. W tym samym okresie liczba placówek zwiększyła się z prawie 4,3 tys. do ponad 4,4 tys. ${ }^{15}$.

Napływ kapitału zagranicznego prowadzi do licznych konsolidacji banków i w konsekwencji do koncentracji sektora bankowego. Powstałe w ten sposób duże banki zagraniczne mają znaczący wpływ na gospodarkę, pomagając bądź przeszkadzając osiągnąć niektóre cele polityczne i gospodarcze. Poza tym w przypadku ewentualnego kryzysu banki zagraniczne najprawdopodobniej skoncentrują się na ochronie swoich interesów, pozostawiając interesy firm polskich i polskiej gospodarki na drugim planie. Ze względu na silne powiąza-

\footnotetext{
${ }^{13} \mathrm{R}$. Brzoza, Zagranica kontroluje polskie banki, Gazeta Gospodarcza nr 47/2003.

${ }^{14}$ Z. Zawadzka, Przemiany w bankowości światowej i ich wpływ na system bankowy w Polsce, http://www.tp-forumbiznesu.pl/referaty/zzawadzka.html?czesc=3

${ }^{15}$ K. Pączkowski, Zagranica kontroluje polskie banki, Gazeta Gospodarcza nr 47/2003.
} 
nie systemu bankowego $\mathrm{z}$ innymi gałęziami gospodarki upadki lub likwidacje zagranicznych instytucji finansowych mogą przynieść wysokie koszty materialne i społeczne.

\section{Zakończenie}

Napływ kapitału zagranicznego prowadzi do licznych konsolidacji banków i w konsekwencji do koncentracji sektora bankowego. Koncentracji sprzyjają bezpośrednie inwestycje zagraniczne lokowane w tym sektorze. Do końca marca 2004 r. ich wartość przekroczyła 7,2 mld zł, a inwestorzy zagraniczni kontrolowali 46 banków komercyjnych i posiadali $61 \%$ udziału w ich strukturze własnościowej. Dzięki inwestycjom nastąpił rozwój sektora bankowego, inwestorzy dofinansowali istniejące banki, poprawili infrastrukturę $\mathrm{i}$ wnieśli wiele innowacji. Powstałe w wyniku koncentracji duże banki zagraniczne mają znaczący wpływ na gospodarkę. Sprawny system bankowy sprzyja rozwojowi gospodarczemu kraju, jednak przeważający udział dużych banków zagranicznych utrudnia politykę finansową państwa i uwrażliwia nasz sektor finansowy na wahania koniunktury i kryzys światowego systemu bankowego.

\section{Literatura}

50 największych banków w Polsce. Miesięcznik Bank, edycja IX, marzec 2004.

BOŻYK P. (red.), Egzemplifikacja międzynarodowych stosunków gospodarczych, WSHiP, Warszawa 2004

BRZOZA R., Zagranica kontroluje polskie banki, Gazeta Gospodarcza nr 47/2003.

DURKA B., Inwestycje zagraniczne w Polsce. Raport roczny. IKiCHZ, Warszawa 2003.

Fuzje i przejęcia bankowe, Zeszyty BRE Bank - CASE nr 45, Warszawa 1999.

Lista inwestorów zagranicznych w Polsce. PAIZ, Warszawa 1993.

PAC R., Inwestycje zagraniczne w polskim sektorze bankowym i ubezpieczeniowym. [w:] Inwestycje zagraniczne w Polsce. Raport roczny, IKiCHZ, Warszawa 2004.

PAWŁOWSKA M., Wpływ zmian w strukturze polskiego sektora bankowego na jego efektywność w latach 1997-2002, Bank i Kredyt, listopad-grudzień 2003.

PACZCKOWSKI K., Zagranica kontroluje polskie banki, Gazeta Gospodarcza nr 47/2003. Sytuacja finansowa banków w I kwartale 2004 r. Synteza. Raport NBP. Warszawa 2004. The list of major foreign investors in Poland. PAIZ, Warszawa 2004.

ZAWADZKA Z., Przemiany w bankowości światowej i ich wpływ na system bankowy w Polsce, http://www.tp-forumbiznesu.pl/referaty/zzawadzka.html?czesc $=3$ ZORSKA A. (red.), Korporacje międzynarodowe w Polsce, Difin, Warszawa 2002. 


\title{
Concentration Processes in Polish Banking Sector
}

\begin{abstract}
The financial sector presents the strongest tendency towards capital concentration, what is the effect of its deregulation, liberalization and strong competitiveness. Fusions and foreign investors, who are taking banks over, are accomplishing this concentration. From the beginning of 1993 until the first quarter of 2004, the number of active commercial banks decreased from 87 to 59 and 27 fusions and assumptions were noticed. At the beginning of 2004 foreign investors controlled 46 commercial banks out of 59 operating in Poland. The value of their investments exceeded 7.2 billions PLN and they owned $76.3 \%$ of equity and supplementary funds and $67.4 \%$ of assets. Owing to these investments, the banking sector development has started and the investors subsidised existing banks, improved infrastructure and made many innovations. The large foreign banks, which were set up as a result of concentration, made banking system more effective and facilitated development of national economy. On the other hand, the superior contribution of large foreign banks obstructs national financial policy and makes the financial sector sensitive to prosperity fluctuations and a crisis of the world banking system.
\end{abstract}

